\title{
THE DEPRIVATIZATION OF EMPLOYEE BENEFIT AND LABOR LAW: THE SURPRISING CONSERVATIVE EROSION OF TRUSTS AND OF THE COMPETITIVE LABOR MODEL
}

\author{
Michael T. Leibig*
}

\section{INTRODUCTION}

\section{Labor Policy Approaches in the Post-Reagan Era}

The accepted wisdom holds that liberal Democratic control of the national government means pro-labor government with the federal authority as a strong advocate of private sector intervention on behalf of workers and their unions, while more conservative Republican administrations favor corporate volunteerism, marketplace labor policy, and the exclusion of governmental workplace intervention. Closely akin to and allied with this dichotomy is a reading of very recent labor history, shared by neo-conservatives and socalled neo-liberals alike, which pictures the post-World War II American workplace as suffering under overly powerful "bread-and-butter" unions. On this reading, the powerful unions have caused America to lose the highly competitive battle with the Japanese for world markets and economic leadership. This neo-labor policy perspective rests on the myth that by forcing higher and higher non-market pay rates and benefit levels the overly aggressive unions pushed the world's leading auto producers to ruin.

A close look at two current labor policy issues raises serious questions about whether these stereotypes reflect reality. An examination of both the Reagan Administration's erosion of the common law trust rules that govern the control of employee benefit investments, and its suggestions concerning a desertion of the half-century old competitive model in labor law, raise doubt about the validity of the stereotypical analysis of the relationship between labor and the government. Pressure toward strict governmental regulation of

\section{Copyright $\odot 1987$ by Law and Contemporary Problems.}

This article is an updated and revised version of an earlier article published under the title $A n$ Erosion of Trust: ERISA's Challenge to Prudent Self-Regulation of Pension Investments, by Michael T. Leibig and Rachel K. Sartwell in 9 J. Pension Plan. \& Compliance 357 (1983). Copyright $\odot 1983$ by Panel Publishers, Inc. By permission.

* Partner, Zwerdling, Paul, Leibig, Kahn \& Thompson, P.C.; Adjunct Professor of Law, Georgetown University Law Center; General Counsel, International Union of Police Associations, AFL-CIO.

The author wishes to thank Ingrid Coney, who contributed greatly to this article. 
employee benefit investment decision making, which was traditionally controlled by private and independent nongovernmental trustees, and an expressed interest in abandoning the National Labor Relation Act's competitive free labor market model for a more "cooperative" framework, each reveal a surprising conservative tendency toward central economic control over employment and its benefits. Such central control traditionally has been resisted even by more liberal governments.

Government control of the workplace may not always favor the traditional beneficiaries of government intervention. As large corporate and financial interests become more concentrated, and as they increase their influence over both the government and the economy, pressure mounts for centralized corporate management of the hundreds of billions in trusteed employee benefit assets, and toward increased corporate volunteerism and workplace cooperation. The erosion of trusts and the desertion of a competitive labor relations model are both symptoms of the new American economy dominated by corporate antitrust evasions, special acquisitions, takeovers, divestitures, mergers, leveraged buy-outs, insider deals, financial strategies, investment banking's juvenile millionaires, and extraordinary money managers. ${ }^{1}$ The current pressure toward the deprivatization of employee benefit investment and employee relations decisions endangers traditional American commitments to decentralized decision making-commitments threatened, surprisingly, by a conservative government.

With the November 1986 election returns and the resulting return of control of the national legislature to Democratic hands, new attention to labor policy is likely. The preference of Edward M. Kennedy, Senator from Massachusetts, for the Chair of the Senate's Committee on Education and Labor, where "old fashion" economic and labor based issues are central, over the Chair of the Judicial Committee, which is concerned with confirmation of federal judicial appointees, including Supreme Court Justices, where the focus is more likely to be on the "yuppie" and social issues such as abortion, prayer in public schools, crime, and family, foreshadows new attention to the basic workplace issues.

The new attention to labor policy is also demonstrated by the move of David Halberstam's, The Reckoning, ${ }^{2}$ and Arthur Schlesinger, Jr.'s The Cycles of American History, ${ }^{3}$ toward the head of the national nonfiction best seller lists. Each offers a new, but not a "neo-," view of the issues that explain the decline of old labor issues in the United States. Halberstam looks carefully at the battle between Ford Motor Company and Nissan and attributes Ford's failure more to bloated management, declining competition, and labor management buddyism than to overly aggressive labor. Schlesinger looks again at the ebb

1. See J. Adams \& J. Brock, The Bigness Complex: Industry, Labor and Government in the American Economy (1986); J. Strohmeyer, The Crisis in Bethlehem: Big Steel's Struggle to SURVive (1986).

2. D. Halberstam, The Reckoning (1986).

3. A. Schlesinger, Jr., The Cycles of American History (1986). 
and flow of thirty-year cycles in American political history and argues that a private interest (Reagan Revolution) cycle is scheduled to end by 1990 and that a new public purpose (Kennedy-Roosevelt) cycle is about to dawn.

There can be no question that today some confusion exists about the place of the working person in American public policy. One leading neoDemocratic candidate for the Presidency, Gary Hart, writes of $A$ New Democracy: A Democratic Vision of the 1980's and Beyond ${ }^{4}$ without providing any serious discussion of labor policy or the everyday workplace problems; meanwhile, New York's Governor Mario Cuomo, the current leading torch bearer of traditional Democratic liberalism, speaks regularly of declining union membership and the need for new cooperation between labor and management along lines first outlined by Herbert Hoover before the Depression. ${ }^{5}$ A new discussion of the position of the working person and of organized labor in America is needed; fortunately, it has already begun. The American Catholic Bishops issued a letter on the economy which is critical of current planning and priorities. ${ }^{6}$ The letter warned that:

Partnerships between labor and management are possible only when both groups possess real freedom to influence decisions. This means that unions ought to continue to play an important role in moving toward greater economic participation within firms and industries. Workers rightly reject calls for less adversarial relations when they are a smokescreen for demands that labor make all the concessions. ${ }^{7}$

The AFL-CIO, in response to declining membership and national opinion poll results, has issued a report on "The Changing Situation of Workers and Their Unions" which emphasizes that "[w]e understand that confrontation and conflict are wasteful and that a cooperative approach to solving shared present and future problems is desirable." 8 The counsel to the United Electrical Workers has argued in The Washington Post for "bigger unions, and fewer of them."9

This article reviews two aspects of a conservative sponsored deprivatization of the American workplace: (1) recently centralized constraints on trustees of employee benefit funds; and (2) the contest between a cooperative and a competitive model of labor relations.

A look at the erosion of traditional American commitments to common law trust rules in the management of pension trusts, and at a labor relations model based on competition raises serious questions about where the country might be going. Is the wave of the future a search for something newer,

4. G. Hart, A New Democracy: A Democratic Vision for the 1980's and Beyond (1984).

5. M. Cuomo, Statement in Television Campaign Appearance (WNBC, Oct. 19, 1986); see also Hawley, Herbert Hoover and Modern American History Fifty Years After, 126 CoNG. REC. S1931 (Feb. 27, 1980); J. Holf-Wilson, Herbert Hoover: Forgotten Progressive (1975); R. Smith, AN Uncommon Man: The Triumph of Herbert Hoover (1984). Hawley, Holf-Wilson, and Smith are cited and discussed in A. SChLESINGER, supra note 3, at 375-387.

6. National Conference of Catholic Bishops, Economic Justice for all: Catholic Social Teaching and the U.S. Economy 42 (3d draft June 4, 1986).

7. Id. at 82 .

8. AFL-CiO, The Changing Situation of Workers and Their Unions 6 (1985).

9. Compa, To Cure Labor's Ills: Bigger Unions, Fewer of Them, Wash. Post, Nov. 16, 1986, at K-1, col.2. 
bigger, and more centralized; or is it a renaissance of past commitments to freer, smaller, decentralized methods of decision making? The future presents two choices. The first offers a society in which the affluent and the successful are big, centralized, and fostered by governmental policy. The alternative is a society of reinvigorated models of decentralized, noncorporate decision making, emphasizing private protection of individual economic rights. The choice is not simple; it confuses categories of the accepted wisdom about what is liberal and what is conservative, about what is procorporate and what is pro-worker.

\section{II}

\section{An Erosion in Trust: ERISA's Challenge to Prudent Self-Regulation of Pension Investments}

Frederick Maitland, the great historian of English common law, wrote, "[i]f we were asked what is the greatest and most distinctive achievement performed by Englishmen in the field of jurisprudence I cannot think we should have any better answer than this, namely, the development from century to century of the trust idea."10 Today, however, federal administrators experience increasing difficulty regulating investment practice under codified trust principles.

This is the story of an erosion of trust. The Pension Reform Act of 1974 (the Employment Retirement Income Security Act, or ERISA) initiated regulatory practices that threaten a superior system of self-regulation. ${ }^{11}$ ERISA was a very significant reform; it is restructuring employee benefit rights in the United States. Federal regulation is displacing traditional American reliance on prudent self-regulation for the responsibility of managing $\$ 600$ billion in employee benefit trusts.

The need for legislation protecting pension and benefit rights had been clear for decades. Employee benefits lacked enforceable, long-term protection. Without legislation requiring funding, vesting, and full reporting and disclosure, pre-ERISA benefit promises were unreliable. The closing of a major corporation would have left thousands of employees holding unenforceable benefit promises. The losses experienced in the early 1960's with the collapse of Studebaker were dramatic, eventually paving the way for federal regulation of pension law.

In enacting ERISA, Congress properly displayed a lack of faith in corporate America's pension practices. More questionable was Congress' weakened allegiance to traditional trust law protections against fiduciary abuse. The fiduciary provisions of ERISA sought to advance the centuries-

10. F. W. Mattland, Selected Essays 129 (1936).

11. 29 U.S.C. $\$ \S 1001-1461$ (1982 \& Supp.). For full support of the ERISA erosion of trust theory, see also Leibig, You Can't Do That With My Money-A Search for Mandatory Social Responsibility in Pension Investments, $6 \mathrm{~J}$. Pension Plan. \& Complance 358 (1980); Leibig \& Rabinowitz, Social Investments and the Regulation of Pension Investments: An Outline of Basic Materials, 9 J. Pension Plan. \& Compliance 173 (1983). 
long development of trust law-Maitland's "most distinctive achievement of English jurisprudence"-one step further. But Congress imposed on that system concepts of rulemaking and agency enforcement which were contrary to its central precepts. That imposition threatens the flexibility, freedom, and growth experienced under the prevailing, privately enforced, self-regulating fiduciary system.

ERISA's system of fiduciary control is more costly, more intrusive, and more burdensome than the system it superseded; it is also less flexible and less efficient. ERISA requires federal economic planning and investment regulation without guidelines or expertise. It results in the generation of mechanical, quantitative rules to control qualitative decisions, forcing out the smallest, most responsive, and often the most successful trustees. Agency regulation of investment decision making cannot succeed in the American financial environment. Traditional self-regulating trust law could do a superior job.

\section{A. Common Law Fiduciary Rules: Principles of Trust}

1. The English Foundation. Professor Isaacs wrote that "next to contract, the universal tool, and incorporation, the standard instrument of organization, [trusteeship] takes its place whenever the relations to be established are too delicate or too novel for these coarser devices." 12 Trusts developed with the division of courts between equity and law. The early chancery courts acted in personam, imposing duties on trustees, while the courts of law enforced the plaintiffs' rights.

Sir Edward Coke battled Lord Chancellor Ellesmere over differences between the rule of law and the equities of the specific case. Professor Maitland saw "civil war and utter anarchy" 13 avoided only by the "great elasticity and generality" that equity provided. ${ }^{14}$ Sir Francis Bacon viewed the creation of trusts as a safeguard against both the anarchy threatened by resistance to inflexible courts of law and the tyrannical control threatened by the imposition of their edicts. ${ }^{15}$

Professor Scott points out that the early chancellors succeeded "because they acted pragmatically rather than logically." 16 They dealt with each case on its own merits, not as an occasion for rulemaking.

If they had been trained in jurisprudence they could hardly have developed the concept of the use or trust. If they had been compelled to classify it [by legal category] their freedom would have been much impaired. The truth is that under the guise of enforcing personal duties they were evolving a new form of property interest.... It can [now] be recognized that law and equity do conflict . . . and that equity has triumphed. ${ }^{17}$

12. Isaacs, Trusteeship in Modern Business, 42 HaRv. L. Rev. 1048, 1060-61 (1929).

13. F. W. Mattland, Equitr: A Course of Lectures 17 (J. Brunyate rev. 2d ed. 1936).

14. Id. at 23.

15. A. W. Scott, Abridgement of the Law of Trusts 5 (1960).

16. A. W. ScotT \& W. Fratcher, Scott ON TRUSTS 8 (4th ed. 1987).

17. Id at 8-9. 
The English evolution of trusts established a triumph of freedom, pragmatism, and flexibility. It generated an appreciation of decentralized, self-regulated trust management and an awareness of each trust management decision as uniquely unsusceptible to simplistic rule.

2. American Developments. English trust law flourished and developed in America. However, three developments are distinctly American.

a. Corporate and professional trustees. As late as 1743, England restricted corporate fiduciary service. American corporate trusts have operated widely since the 1822 charter of Farmer's Fire Insurance \& Loan Company. ${ }^{18}$ English trustees still receive no compensation unless expressly provided for in the trust document, whereas American trustees have always been provided reasonable compensation. ${ }^{19}$ Corporate and professional fiduciaries fostered the growth and increased the attractiveness of American trusts.

b. Codification. The United States has subjected trusts to statutory provision since the nineteenth century. The statutes were confined, however, to the codification of accepted common law principles. Until recently, administrative rulemaking was avoided. By standardizing trusts while preserving fiduciary flexibility and self-regulation, codification encouraged their use in funding employee benefits.

c. The prudence principle and Harvard College v. Amory. Finally, the most important American contribution to the law of trusts is the "prudent man rule," enunciated in Harvard College v. Amory. ${ }^{20}$ In 1830, Harvard College and Massachusetts General Hospital complained that Amory, the trustee of $\$ 50,000$ of which they were the eventual beneficiaries, had mismanaged the trust and lost $\$ 20,550.21$ Amory had purchased shares in insurance and manufacturing companies. He argued that he was charged with the care of the fund, and that he had legitimately exercised personal discretion in its care.

Harvard and Massachusetts General countered that Amory had invested in "trading companies, and so exposed the capital to great loss," and that "insurance and manufacturing stocks [were] not safe, because the principle is put at hazard."22 The institutions also asked that Amory's investments be prohibited since his intent in seeking a high return had been partially to benefit the trust grantor's wife rather than to benefit solely the trust's ultimate beneficiaries. Massachusetts Chancery Justice Samuel Putnam favored Amory:

All that can be required of a trustee to invest, is, that he shall conduct himself faithfully and exercise a sound discretion. He is to observe how men of prudence, discretion, and intelligence manage their own affairs, not in regard to speculation, but in regard

18. Id. at 27-28.

19. Id. at 28 .

20. 26 Mass. (9 Pick.) 446 (1830).

21. Id. at 450 .

22. Id. at 455 . 
to the permanent disposition of their funds, considering the probable income, as well as the probable safety of the capital to be invested. ${ }^{23}$

The decision established the prudent man rule. It departed from the more conservative English rule that required an absolute commitment to the preservation of the trust capital. The American rule gave more flexibility to trustees and money managers in a young, expanding nation. Recognizing that there is often no "bright line" dividing safe and unsafe investments, the prudent man standard eliminated risk as the sole basis for evaluating securities. Rather, the standard could be more flexible, considering the potential return as well. ${ }^{24}$ With Harvard College $v$. Amory, prudence became the guiding force of American fiduciary decision making.

The true nature of prudence, however, is difficult to define. In his treatise, Prudence, ${ }^{25}$ the German monk, Josef Pieper, examines the nature of this virtue:

To the contemporary mind, prudence seems less a prerequisite to goodness than an evasion of it. The statement that it is prudence which makes an action good strikes us as well-nigh ridiculous.... [W] tend to misunderstand [it] as a tribute to undisguised utilitarianism. . . . In colloquial use, prudence always carries the connotation of timorous, small-minded, self-preservation, of a rather selfish concern for oneself $\ldots 26$

But Pieper's true prudence, and the American prudence rule, are based on realities which form the environment of concrete human action. To Pieper, " $[t]$ he preeminence of prudence means that 'good intentions' and 'meaning well' by no means suffice. Realization of the good presupposes that our actions are appropriate to the real situation ... and that we therefore take this concrete reality seriously, with clear-eyed objectivity." 27

Prudent action is not fostered by simplistic rules applied without reference to the facts, but is only possible case-by-case. Prudent action cannot be directed by strict formulae. To require prudence of fiduciaries is to trust their selfregulation as the only option sensitive enough to respond realistically to the complicated requirements of investment decision making.

During the first three quarters of this century, America fostered selfregulation of prudently managed trusts. Trusts became the preferred method of funding employee benefit plans. By 1974 , such trusts successfully managed nearly $\$ 300$ billion under provisions which would double that amount before 1984. Inadequate provisions for actuarial funding, vesting, and disclosure of employee benefits-not a failure of traditional fiduciary control-generated the need for ERISA. A privately enforced application of the trust duties of care, loyalty, and prudence by independent private fiduciaries had proven invaluable.

23. Id. at 461 .

24. Note, The Regulation of Risky Investments, 83 HARv. L. REv., 603, 613 (1970); see also Shattuck, The Development of the Prudent Man Rule for Fiduciary Investment in the United States in the Twentieth Century, 12 OHio ST. L.J. 491 (1951).

25. J. Pieper, Prudence (1959).

26. Id. at 14-15.

27. Id. at 25 . 


\section{B. Administrative Rulemaking: Distrust and the Temptation to Control}

During the same seventy-five years in which common law trust concepts led to the self-regulation of employee benefit investments, American administrative rulemaking developed as a more controlled system of economic regulation. As early as 1927, Felix Frankfurter viewed the development of administrative law just as Professor Scott viewed the accidental development of equity. Frankfurter wrote: " $[w] e$ are in the midst of a process, largely unconscious and certainly unscientific, of adjusting the exercise of [agency] powers to the traditional system of Anglo-American law and courts." 28

By 1942, future Supreme Court Justice Wiley Rutledge recognized "the emergence of a new system, not less significant than the evolution of chancery." 29 Frankfurter later commented that "[l]egal scholars have rightly compared [the rise of administrative law] to the rise of equity."30 Dean James Landis noted that "[a]s rapidly as-indeed, sometimes more rapidly thancauses could be isolated and problems defined, administrative agencies were created to wrestle with them." 31

Administrative law is a powerful tool. It combines rulemaking, adjudication, and agency enforcement to create remedies for problems of mass society with which no other legal tool can deal as equitably and realistically. Administrative agencies concentrate expertise for controlled problem resolution. The predisposition of administrative law for centralized regulatory control, however, necessarily conflicts with the more subtle requirements of self-regulating prudence.

In many areas of health, safety, and economic activity, rulemaking is ideal. Equity pushed law aside from areas in which equity served best; so too, administrative law has triumphed in many areas of American life. However, just as Professor Isaacs found contract and corporate law too coarse to cope with the delicate and novel problems resolved by trusts, administrative law is equally ill-fitted to the most sensitive trust problems. Centralized decision making, standardized guidelines, and concentrated expertise do not suit investment planning.

Administrative law is susceptible to three relentlessly popular criticisms"straightjacketing," "industry capture," and "politicization." Regulation causes a reduction in creative flexibility through the expanding straightjacket and the related "tar baby effect." Straightjacketing occurs when an agency must act without quantitative standards, exact boundaries, or precise guidelines. Standardized rules are difficult to formulate where flexible qualitative judgment and decentralized personal decision making are necessary. Furthermore, once underway, ill-fitted regulatory management

28. Frankfurter, The Task of Administrative Law, 75 U. PA. L. Rev. 614, 614-15 (1927).

29. Melvin v. Pence, 130 F.2d 423, 426 (D.C. Cir. 1942).

30. Federal Maritime Bd. v. Isbrandtsen Co., 356 U.S. 481, 519 (1958) (Frankfurter, J., dissenting).

31. J. Landis, The Administrative Process 14 (1938). 
results in overregulation. It exerts "effort to enlarge the domain and the specificity of regulation" 32 which will not retreat. The regulated activity becomes more and more restricted under administrative efforts to fit it to rules which do not quite seem to work. Once this expanding straightjacket begins to tighten, the tar baby effect also comes into play. The tar baby effect, ${ }^{33}$ according to Harvard's James $\mathrm{O}$. Wilson, occurs

when an agency applies a regulation, perhaps a quite clear and defensible one, to some single aspect of an enterprise ... only to discover that the effect of its regulation is not what it hoped; as a consequence, it then seeks to regulate additional aspects of the enterprise in order to make the initial regulation 'come out right.' 34

Regulation reduces freedom for expansion and growth through industry capture. Industry capture is the tendency of an agency to be controlled by dominant forces in the industry that it seeks to regulate. Politically sophisticated "bureaucratic clientism" in the airline, railroad, broadcasting, food and drug, and other industries has been described by conservative economist George Stigler, ${ }^{35}$ liberal historian Gabriel Kolko, ${ }^{36}$ and administrative law scholar Louis L. Jaffee. ${ }^{37}$ Professor Wilson expresses the concern that "[a]dministrative regulation will not succeed in constraining business firms to act in accordance with socially valuable objectives because agencies that administer these regulations will be 'captured' by or otherwise serve the interest of the affected industry." 38

Systems of regulation must be administered through politically appointed governmental officials. Accordingly, in any system of regulation, a potential for politicization of the regulatory process occurs. The politicization of investment planning is particularly dangerous because it is at once too flexible and too rigid. The direction of investment based on a single political philosophy is too rigid. The shifting of investment direction based on changes in political administration is too flexible. Both inhibit sound longrange investment planning. Politicization occurs regardless of the philosophy or principles of any given administration. A conservative government might be anti-labor in its investment direction; a labor government might be antibusiness. The politicization problems intensify because the political majority and control of the administrative process change. Decisions with regard to long-term investment planning inevitably bend with the political wind. Direction of large pools of capital through the regulation of pension investments is a constant temptation to both conservative and liberal governments.

32. Wilson, The Politics of Regulation, in Social Responsibility and the Business Predicament 135, 152 (J. McKie ed. 1974).

33. The tar baby effect was first explained by James McKie in McKie, Regulation and the Free

Market: The Problem of Boundaries, 1 BeLL J. Econ. \& MGMT. ScI. 6, 9 (1970).

34. See Wilson, supra note 32 , at 153.

35. Stigler, The Theory of Economic Regulation, 2 BeLL J. Econ. \& MGMt. Sci. 3 (1971).

36. G. Kolko, Railroads and Regulation, 1877-1916 (1965).

37. Jaffe, The Illusion of the Ideal Administration, 86 HARv. L. REv. 1183 (1973).

38. Wilson, supra note 32 , at 157. 
C. ERISA Investment Control and the Desertion of Self-Regulation

1. ERISA's Culmination of Codification. In 1974, a single section of federal law came to dominate the regulation of pension investments. With section 404(a) of ERISA, ${ }^{39}$ Congress sought to complete the American codification of fiduciary standards. That codification is organized around six basic rules derived from the common law; each contains a slight innovation. Table I presents these six rules with their innovations, contrasting section 404(a)'s codified provision with traditional fiduciary concepts.

Congress sought to complete the codification of fiduciary standards by authorizing strict prohibited transaction rules and agency enforcement. Sections 406 through 408 establish absolute prohibitions of specified transactions that offer serious potential for abuse. ${ }^{40}$ The transactions listed are very broad and would prohibit, if literally applied, many transactions previously allowed under common law. Congress attempted to cure the potential difficulties with such broad prohibitions by use of an administrative rule. The Secretary of Labor, after consultation and coordination with the Secretary of the Treasury, was given broad authority to grant individual and class exemptions from the prohibitions. ${ }^{41}$ Part 5 of Title I of ERISA gives each agency extensive enforcement authority.

2. A Break with the Past. As postenactment commentary forecasted, ${ }^{42}$ ERISA's six innovations of the common law revolutionized investment practice. ERISA continues to revolutionize the regulation of pension investments to this day. However, this revolution is not based solely on the statutory provisions. While each innovation certainly has marked a change, each innovation has also continued a previous trend. The radical step away from the preexisting self-regulated system is not the rewording of these rules but their placement within a scheme of federal rulemaking.

Federal regulatory control threatens to push aside self-regulating, privately enforced trust principles as the dominant force in the management of pension investments. Through reduction in investment flexibility, freedom, and growth, federal regulatory control provides a potential for industry capture.

Two recent DOL initiatives highlight these dangers. DOL's unsuccessful litigation theory in Donovan $v$. Walton, ${ }^{43}$ presents an effort to replace a flexible equity standard with a mechanical agency rule and exemplifies the straightjacketing and tar baby effects. A class exemption for Qualified

39. 29 U.S.C. \& 1104 (1982).

40. 29 U.S.C. $\$ \S 1106-1108(1982)$.

41. 29 U.S.C. $\& 1108$ (a) (1982).

42. See generally Hutchinson, The Federal Prudent Man Rule Under ERISA, 22 ViLl. L. Rev. 15 (1978); Lanoff, Reporting and Disclosure and Prudence in Investment Under ERISA, 29 LAB. L.J. 323 (1978); Ravikoff \& Curzon, Social Responsibility in Investment Policy and the Prudent Man Rule, 68 CALIf. L. Rev. $518(1980)$.

43. 609 F. Supp. 1221 (S.D. Fla. 1985) (mem.), aff'd sub nom. Brock v. Walton, 794 F.2d 586 (11th Cir. 1986) (per curiam). 


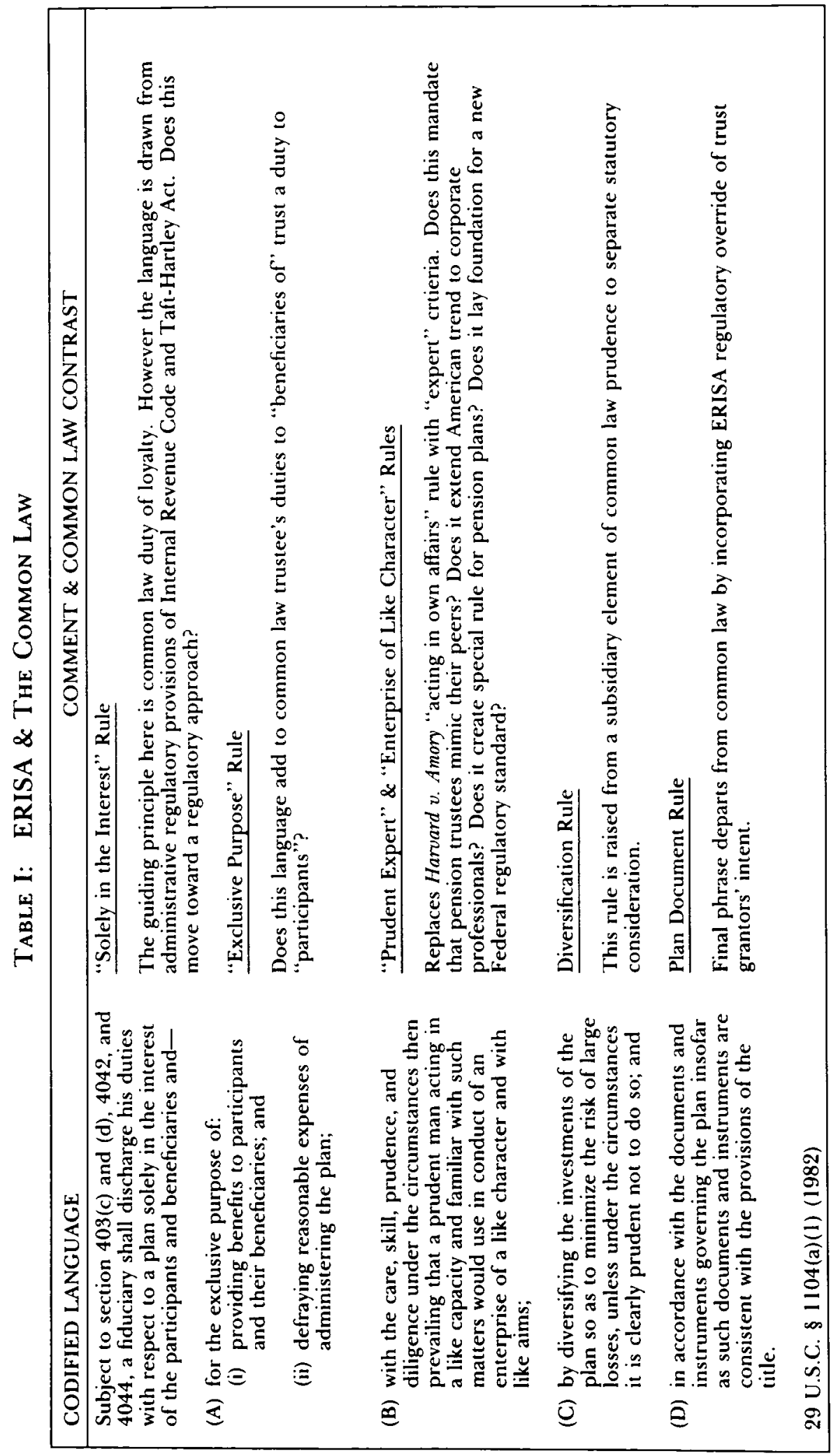


Professional Asset Managers, ${ }^{44}$ provides a classic example of the potential for industry capture.

3. The Threat of Straightjacketing Through Mechanical Rule. As one commentator noted just after ERISA's enactment:

The prudent man standard of the Act does not create exact standards of behavior for fiduciaries but only establishes a general rule. The inherent vagueness of this standard and the need to develop more precise guidelines ... undoubtedly will create initial uncertainty and may cause fiduciaries to be unduly conservative until the parameters of the new standard are defined. ${ }^{45}$

Nearly four years after enactment of ERISA, DOL first issued "prudence rule" regulations that were designed, in part, to correct overly rigid reactions to the statute itself. ${ }^{46}$ They recognized that in the equity tradition, courts, rather than a regulatory agency, should ultimately control the rule's interpretation. DOL emphasized that " $[t]$ he Department is of the opinion that generally, the relative riskiness of a specific investment or investment course of action does not render such an investment per se prudent or per se imprudent." 47 Initially, the codified prudence rule was officially presented as an extension of a flexible common law tradition. No simple per se first criterion test was foreseen. Like his common law forebearer, the ERISA trustee was cautioned to consider carefully all aspects of each specific investment opportunity. He was not to rely on mechanical rules. ${ }^{48}$

Almost immediately, DOL faced the argument that a single per se first criterion rule should be imposed on all investment decision making. Members of the established investment management community argued that with ERISA, return maximization should be the first litmus test of all investments: the trustee should first insure that return is maximized, then apply other fiduciary judgments. ${ }^{49}$ Reverence for that theory, which obviously predated ERISA, resulted in pressure to control investment decision making through an express rule. The agency, however, held to its no per se rule position. Pressure for more definitive opinion letters and regulations mounted.

In January, 1981, a Labor Department advisory opinion letter adopted the view that, "a mortgage interest rate charged by a plan that is below the stated rate of other lenders of similar loans may, under certain circumstances, be a 'reasonable rate of interest' within the meaning of section $408(b)(1)$ of ERISA." 50 This letter, from then DOL administrator Ian Lanoff to the AFL-

44. 49 Fed. Reg. 9,494 (1984).

45. Note, Fiduciary Standards Under the Employee Retirement Income Security Act of 1974, 63 Geo. L.J. 1109,1120 (1975).

46. 44 Fed. Reg. 37,221 (1979).

47. Id. at 37,222 .

48. See Labor Management Services administration, U.S. Dept, of labor, The Prudence Rule and Pension Plan Investments Under ERISA (1980).

49. See generally Employee Benefit Research Insttrute, Should Pension Assets be Managed for Social/Political Purposes, A Policy forum (1979).

50. Letter from Ian D. Lanoff, Administrator, Pension \& Welfare Benefit Programs, to Robert A. Georgine, Chairman, National Coordinating Committee for Multi-Employer Plans (Jan. 15, 1981) 
CIO's Robert Georgine, seemed to some to move toward a reasonable return rule. It became the subject of continuing pressure for more precision. The questions persisted: Was there a reasonable return rule? Could it work? How could fiduciaries operate under its vagueness?

Late in 1981, DOL took the predictable step and attempted to establish a uniform mechanical test for all ERISA investments. In Donovan $v$. Walton, ${ }^{51}$ the DOL brought suit against various trustees of a large union pension fund for breach of their fiduciary duties alleging, inter alia, that a ten percent rate of return on a self-funded construction project was below the prevailing or market rate and that its approval by the trustees, therefore, was a violation of ERISA's prudent person standard.52 After a bench trial in 1983, the district court granted the defendants' motion for summary judgment with respect to the prudence issue and, in a later issued opinion, emphasized the traditional common law derivation of the prudence standard.53

On appeal, the DOL argued that ERISA contained a prevailing rate test restricting ERISA fiduciaries to investments at the "prevailing or market rate of interest." 54 The Eleventh Circuit flatly rejected the DOL theory by holding that a reasonable rate may be different from the prevailing or market rate. ${ }^{\mathbf{5 5}}$ In the absence of additional evidence of imprudence, the rate differential alone was found to be insufficient to defeat the defendants' motion for summary judgment. The Eleventh Circuit's decision ended the DOL's attempt to impose a mechanical test based on the prevailing or market rate of interest as an absolute first criterion of prudence.

4. The Threat of Industry Capture Through Class Exemption. In 1975, both the Labor and Treasury Departments published complex exemption procedures ${ }^{56}$ for ERISA's broad prohibited transaction rules. ${ }^{57}$ In December 1978, under an administrative reorganization, DOL was given sole jurisdiction over exemptions. 58

In 1975, one exemption was approved. Eleven exemptions were approved in 1976. Thirteen were approved in 1977. And twenty-two were approved in 1978. Criticism of the waste and inefficiency of the process spread. In 1979, after a concerted DOL reform effort, eighty exemptions successfully wound

(emphasis in original), reprinted in M. Leibig, Mandating Social Prudence: A Handbook for Pension AND InVESTMENT 52-56 (1982).

51. 609 F. Supp. 1221 (S.D. Fla. 1985) (mem.), aff'd sub nom. Brock v. Walton, 794 F.2d 586

(11 th Cir. 1986) (per curiam).

52. Id. at $1225 \& \mathrm{n} .2,1238$.

53. Id. at 1225-26 \& $\mathrm{nn} .3-4,1238-40$.

54. Brock v. Walton, 794 F.2d 586, 587 (1 l th Cir. 1986) (per curiam), aff'g 609 F. Supp. 1221

(S.D. Fla. 1985) (mem.).

55. Id. at 587-88.

56. 29 U.S.C. \& 1108 (1982 \& Supp.); Labor-Management Servs. Admin., U.S. Dept. of Labor, Standards for Exemption from ERISA Prohibited Transaction Provisions (1980).

57. 40 Fed. Reg. 18,471 (1975); see also 29 U.S.C. $\$ 1106$ (1982) (ERISA $\$ 406$ ). For a discussion of the prohibited transaction rules, see Hutchinson \& Cole, Legal Standards Governing Investment of Pension Assets for Social and Political Goals, 128 U. PA. L. REv. 1340, 1375 (1980).

58. Reorganization Plan No. 4 of 1978, 43 Fed. Reg. 47,713 (1978). 
their way through the agency. ${ }^{59}$ That is a total of less than 140 exemptions in five years! Further criticism ensued. In 1982, 222 exemptions were granted; and during the first quarter of 1983 , over fifty were approved. DOL estimates that nearly 1,000 requests are received annually. About one-third are now granted. ${ }^{60}$

Few exemption requests are flatly rejected, but many fail to complete the process. Irving Baldinger of the American Benefit Plan Administrators reports that "prohibited transaction rulings warn us that this is an area thoroughly mined with booby traps for the unwary. Safe passage may be negotiated, but only by way of an exemption process that is exceedingly tedious, confusing, costly and time consuming." 61 The approval procedure's cost and delay stymie more transactions than DOL disapproves. Jeffrey Clayton, then DOL's program administrator, saw "literally thousands of harmless situations [that are now prohibited]. . . . It takes three to four months to acquire an exemption. . . . [That delay alone] could lose a good investment opportunity."'62 Raymond Donovan, Secretary of Labor at the time, described "plan asset managers [as being] forced to choose between applying for an exemption from the department, or foregoing a sound investment opportunity entirely. Some managers often chose the latter."63

On December 21, 1982, DOL proposed a solution to the inefficiency of its exemption procedure. ${ }^{64}$ Secretary Donovan unveiled the "broadest, most flexible exemption ever proposed" 65 as the centerpiece in DOL's deregulation program. Under the proposal, those employee benefit trustees who turn their investment decision making over to qualified professional asset managers (QPAMs) would be covered by a blanket class exemption.

A QPAM is defined as a bank (including certain savings and loan institutions) with equity capital in excess of $\$ 1,000,000$, an insurance company with net worth in excess of $\$ 1,000,000$, or a federally registered investment adviser managing total client assets in excess of $\$ 50,000,000$ and with equity of at least $\$ 750,000.66$

This regulation is a classic example of industry capture. The QPAM regulations became final on March 13, 1984, with only minor, pro-industry changes. ${ }^{67}$ Its final approval means that benefit plans which are directly

59. Baldinger, Prohibited Transactions-The End of Innocence, 6 J. Pension Plan. \& Compliance 171,172 (1980) [figures updated by author through review at Dept. of Labor and with the help of Phyllis Borzi, Staff Counsel, U.S. House Committee on Education and Labor]; see Leibig \& Sartwell, An Erosion of Trust: ERISA's Challenge to Prudent Self-Regulation of Pension Investments, 9 J. PENSION PLAN. \& Compliance 357, 366 (1983).

60. Noble, U.S. Would Ease Curbs on Pension Investments, N.Y. Times, Dec. 21, 1982, at D1, col. 1.

61. Baldinger, supra note 59 , at 171 .

62. Noble, supra note 60 , at D7.

63. Id.

64. 47 Fed. Reg. 56,945 (1982); see Proposed QPAM Exemption Too Narrow. Should Be Broadened, Commenters Say, 10 Pens. Rep. (BNA) No. 435, at 452 (Mar. 14, 1983).

65. Noble, supra note 60.

66. 49 Fed. Reg. 9,506 (1984).

67. 49 Fed. Reg. 9494 (1984); see Class Exemption Granted to Allow Several Transactions by Asset Managers, 11 PENS. REP. (BNA) No. 12, at 363, 385-97 (Mar. 19, 1984). 
managed by common law trustees are subject to a burdensome administrative process, while those that turn management over to the established investment industry are "deregulated." Ironically, the largest, most professional corporate investment managers, who are most able to deal with the complicated regulatory process, are exempt from it. At the same time, their businesses are substantially subsidized by the special treatment afforded their customers.

DOL emphasizes that the exemption applies only to "established institutions which are large enough to discourage the exercise of undue influence upon their decision making process by parties in interest."68 Labor and trustee organizations disagree and see further danger of industry capture by professional managers in this and related areas. 69

The threats of straightjacketing, industry capture, and politicization are real. The traditional trust theory is that a private fiduciary selected independently by a trust grantor should exercise the skill, care, and prudence exercised in his own personal affairs. That traditional system allowed for sensitivity to the individual needs of each trust. It dispersed investment decision making widely. The system avoided rigidity and centralized control, while preventing politicized investment practice. The traditional trust theory provided for self-regulation and recognized the weakness in any mechanical investment rule.

ERISA now threatens to replace this system with one which operates on the basis of established rules and concentrates investment decision making in "established institutions which are large enough to discourage" influence by those with an interest in the management of the trust. This signals an erosion of trust. A federal codification of traditional fiduciary concepts is being overtaken by a distrust of independent fiduciaries so complete that the greatest strengths of traditional self-regulating prudence are in danger of being lost.

\section{A Return to Trusts and Self-Regulation of Pension Investments}

A reappraisal of ERISA's investment controls is in order. Full disclosure, benefit protection, and anticorruption enforcement must be maintained. However, mechanical investment rules or class exemptions that fail to recognize the importance of decentralization, flexibility, and widely dispersed, individually-exercised investment control must be abandoned.

DOL should relax the presumption which prohibits transactions unless expressly exempted. If, after thirty days notice, the DOL does not intercede, a non-self-serving fiduciary should be encouraged to proceed with a particular investment. ${ }^{70}$

68. Noble, supra note 60 , at D7.

69. See Fosco, Multiemployer Pension Plans Are Not Wall Street Investment Funds, NCCMP UPDATE, Summer 1986, at 11,13 .

70. See Baldinger, supra note 59 , at 177 . 
Self-regulated investment decision making has a longer, more successful, and more sensible record than ERISA administrative control can ever establish. Congress should reestablish common law trusts, and abandon rulemaking as the primary guide to ERISA investment decision making.

\section{III}

\section{The Desertion of the NLRA Competitive Model}

During the 1930's, the United States made a basic policy commitment designed to generate and protect a strong decentralized national labor market. The findings and policy statements included in the National Labor Relations Act (NLRA) set a course for private sector employee relations on the basis of a national policy commitment to privately negotiated collective bargaining contracts. That commitment has dominated union activity in the United States for fifty years.

\section{A. The NLRA's Policy Directive}

Section 1 of the National Labor Relations Act declares it to be the policy of the United States

to eliminate the causes of certain substantial obstruction to the free flow of commerce and to mitigate and eliminate these obstructions when they have occurred by encouraging the practice and procedure of collective bargaining and by protecting the exercise by workers of full freedom of association, self-organizing, and designation of representatives of their own choosing for the purpose of negotiating the terms and conditions of their employment or other mutual aid and protection. ${ }^{\prime 1}$

The NLRA expressly finds that the denial of unionization rights injures not only workers, but the country and its economy as a whole. ${ }^{72}$ It emphasizes that the inequity of bargaining power between workers and "employers who are organized in corporate or other forms of ownership association, substantially burdens" the economy. ${ }^{73}$ Further, it finds that "experience has proven" that the protection of the right to organize safeguards commerce, reduces workplace strife, and encourages the friendly adjustment of industrial disputes. ${ }^{74}$ The NLRA proposed, and today claims to protect, private sector unions and strikes as the marketplace counter to concentrated corporate power.

The problem addressed by the NLRA was the inequality of economic power between employers and employees in the pre-NLRA economy. This unequal economic power existed, in part, because the government had protected and nurtured corporations and other forms of organized joint ownership while discouraging the economic consolidation of workers into unions and enjoining workers' concerted strike activity. The NLRA redressed this imbalance by protecting worker self-organization and concerted activity,

71. 29 U.S.C. $\S 151$ (1982).

72. Id.

73. Id.

74. Id. 
and by establishing a bargaining process while leaving the parties free to set wages, hours, and working conditions.

The basic model permits the private bargaining process to establish labor costs. Under the NLRA model, if management is unfair or pays insufficient wages, labor may withhold its services by means of a strike. The strike puts economic pressure on management because during the strike, management cannot produce its products or services and thereby loses out economically. The strike puts economic pressure on workers because they are not paid while out on strike. Under the model, sacrifices on both sides should lead the parties to a settlement acceptable to both management and labor. The government leaves it to management and labor to settle their disputes over the costs of labor through this private self-help mechanism. The government protects the property rights of management through established common law and corporate law. It protects the right to concerted labor activity and collective bargaining through the NLRA. It protects both through a national labor policy based on private decision making.

The theory underlying the NLRA is one of economic competition, power balancing, self-help, and protection of concerted activity through strikes, as vital to properly functioning labor markets. The NLRA's statement of findings and policies ${ }^{75}$ makes no special or express reference to a need to increase cooperative communications, to foster merit principles, or to intrude on behalf of the public as the third party at the bargaining table. While the benefits to society of a smooth, efficient economy, free from interruptions due to industrial strikes are emphasized, there are no provisions to avoid the potential damage of protracted strikes, or to foster other cooperative, protectionist, or paternalistic models.

1. The NLRA Model and Its Alternatives. The NLRA model is based on a policy assumption which expressly favors the organization of workers into unions which are granted exclusive bargaining power. The act is intended to foster a national program of employee organizations, operating as independent, separately empowered centers of market decision making outside the government. The NLRA, a design for workplace democracy, was intended to result in joint workplace decision making through competition. It is very important to place that concept of worker rights into the historic framework of the 1930's and the alternative models offered at the time. ${ }^{76}$ The 1930's presented three alternate economic models-socialism, fascism, or corporate volunteerism. The socialist alternative would have involved nationalization of the means of production and was not a realistic alternative in the American political and economic context.

The fascist alternative, which prior to World War II and the Holocaust was not as quickly dismissed as it is today, would have offered a national arrangement of joint worker-employer organizations with mandated wages

75. Id.

76. See C. Gregory \& H. Katz, Labor and the Law 223-52 (3d ed. 1979). 
and controlled prices set in a framework of government sponsored cooperative structures. Fascist theory required mandatory participation of all employees, professional and nonprofessional alike, in worker leagues, guilds, or unions. The government would tightly control the relationship between those employee organizations and mirror management structures. Economic strength, world competitivism, domestic economic cooperation, and central control were the object of the design. The system, credited to Mussolini, "made Italy's trains run on time," generated a tremendous German reawakening, built Japan into a world power, and was widely copied in South America. ${ }^{77}$

The third alternative, advanced by Herbert Hoover and others, advocated utilizing advanced technology and new management techniques. Corporate protection and volunteerism had dominated American labor policy since the earliest stages of the industrial revolution. In the nineteenth century, Henry Charles Carey called for a cooperative economy of associations "to prevent the process of separation of [capital and labor]." 78 Hoover's views on labor relations are largely unknown today. They would surprise many and are strangely similar to the cooperative model offered by the Japanese today. John L. Lewis, the grandfather of American labor, was a strong Republican in the 1920's. In 1928, he called Hoover "the foremost industrial statesman of modern times." 79 Hoover, a mining executive before becoming a politician, described his ideas on the management of a mine in 1905:

The older mines ... were at that time very reactionary in their mining methods and in their treatment of labor. Strikes were frequent. We encouraged the unions by collectively bargaining with them. There were no strikes in our mines during anytime. ... Our operations were a demonstration, an industrial fundamental greater technical service, more labor-saving devices, lower costs, and larger production for higher wages. ${ }^{80}$

Each of the three models was rejected in favor of the less centralized, free market-oriented power balancing of the NLRA. No one at the time believed that the NLRA model could work unless it affirmatively fostered the growth of effective, widespread unionism as the workers' representative in the workplace. $^{81}$

\section{B. The NLRA's Commitment To Union Growth}

As Paul Weiler has shown in some detail, the NLRA's encouragement of unionization worked well:

When the NLRA was enacted in 1935 union density - the ratio of union membership to the nonagricultural workforce - was only $13 \%$. In just one decade, union density nearly tripled, reaching $35 \%$. After a postwar dip, union membership returned in

77. See generally S. Payne, Fascism: Comparison \& Definition (1980).

78. A. Schlesinger, supra note 3, at 232 (citing Carey's Manual of Social Science 516 (K. McKeon ed. 1864)).

79. Id. at 37.

80. H. Hoover, The Memoirs of Herbert Hoover, 1874-1920, at 75 (1951); see supra note 5.

81. C. GREGory \& H. KATZ, supra note 76, at 223-52. 
1954 to near the $35 \%$ level. Then began the slide - to less than $30 \%$ by 1965 , and to just over $20 \%$ by $1980 .^{82}$

Weiler offers the following graphic representation of the increase in which density:

TABLE II

Union Density in the United States, 1935-198083

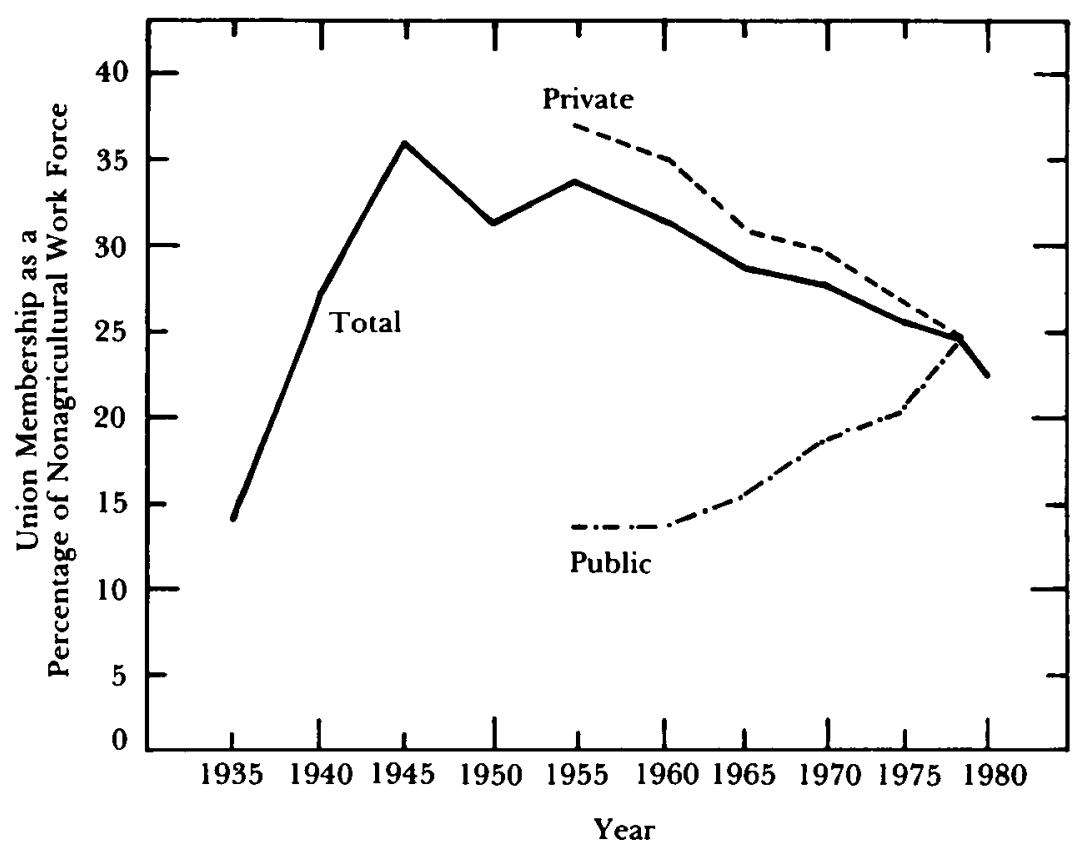

During the early 1940's, unions won eighty percent of certification elections. The NLRA policy successfully nurtured the development of unions and collective bargaining into the mid-1960's. Again, Weiler has marshalled that data. ${ }^{84}$

82. Weiler, Promises to Keep: Securing Workers' Rights to Self-Organization under the NI.R.t, 96 HARv. L. Rev. 1769, 1771 (1983).

83. Id. at 1772 .

84. Id. at 1776 . 
TABLE III

The Contribution of NLRB Elections to Union Growth, 1950-1980

\begin{tabular}{|c|c|c|c|c|}
\hline Year & $\begin{array}{c}\text { Certification } \\
\text { Elections } \\
\text { (Eligible Voters) }\end{array}$ & $\begin{array}{c}\text { Union Victory } \\
\text { Rate }\end{array}$ & $\begin{array}{l}\text { Fraction of Voters } \\
\text { (Number of Voters) } \\
\text { in Union Victories }\end{array}$ & $\begin{array}{c}\text { Fraction of } \\
\text { Nonagricutural } \\
\text { Work Force in } \\
\text { Union Victories }\end{array}$ \\
\hline 1950 & $\begin{array}{c}5619 \\
(890,368)\end{array}$ & $74 \%$ & $\begin{array}{c}85 \% \\
(753,598)\end{array}$ & $1.92 \%$ \\
\hline 1955 & $\begin{array}{c}4215 \\
(515,995)\end{array}$ & $68 \%$ & $\begin{array}{c}73 \% \\
(378,962)\end{array}$ & $0.87 \%$ \\
\hline 1960 & $\begin{array}{c}6380 \\
(483,964)\end{array}$ & $59 \%$ & $\begin{array}{c}59 \% \\
(286,048)\end{array}$ & $0.62 \%$ \\
\hline 1965 & $\begin{array}{c}7576 \\
(531,971)\end{array}$ & $61 \%$ & $\begin{array}{c}61 \% \\
(325,698)\end{array}$ & $0.64 \%$ \\
\hline 1970 & $\begin{array}{c}7773 \\
(588,214)\end{array}$ & $56 \%$ & $\begin{array}{c}52 \% \\
(307,104)\end{array}$ & $0.53 \%$ \\
\hline 1975 & $\begin{array}{c}8061 \\
(545.103)\end{array}$ & $50 \%$ & $\begin{array}{c}38 \% \\
(208.313)\end{array}$ & $0.33 \%$ \\
\hline 1980 & $\begin{array}{c}7296 \\
(478,821)\end{array}$ & $48 \%$ & $\begin{array}{c}37 \% \\
(174,983)\end{array}$ & $0.24 \%$ \\
\hline
\end{tabular}

Why did union density decline so dramatically after the mid-1960's? During that period, many changes occurred in union organization, employees' self-interest in organizing, and management resistance to unionization. However, it is very clear that since the mid-1960's, the NLRA policy directive encouraging collective bargaining as the preferred model for employee relations simply has failed to generate the intended level of union organization. Today, the NLRA model, under which private sector unions are intended to operate as significant market forces in the protection of labor and in lending counterweight to concentrated corporate power, is facing rough times. More and more, the corporate structures of the country are collapsing into a concentrated center of financial decision making.

As Lance Campa, counsel for the United Electrical Workers recently noted: "[a] spiral of acquisitions, takeovers, divestitures, mergers, leveraged buyouts and other gameboard moves by management began in earnest in the 1960 's, paused for breath in the 1970's, and has taken off to new heights in this decade." 85

A soaring national debt acts as a governmental transfer program from taxpayers to bondholders-that is, from labor to capital, from average working people to wealthier people, from those who work for wages to those who own the corporations they work for. With Reaganomic budgets, governmental transfers from the wealthy to the middle-class evaporate. The tax code is reformed to slash taxation of the wealthy. Political action committees make corporate donations a driving force in political campaigns. Antitrust enforcement evaporates. Without strong nongovernmental, noncorporate power

85. Campa, supra note 9 , at K-2. 
centers, concentrated financial power is at least as serious a problem today as it was in 1935 when the NLRA competitive union counterweight model was developed. Consequently, the increased economic power of the corporate employers makes it more likely that workplace decisions increasingly will be subject to unilateral employer action. To counter the increased corporate power, some have called for an analogous increase in union power through "bigger and fewer unions." 86

\section{DOL Study Questions the Competitive NLRA Model}

Into this environment, the Department of Labor issued a report on the future of American Labor. ${ }^{87}$ The report, prepared by Deputy Undersecretary of Labor-Management Relations and Cooperative Programs, Stephen I. Schlossberg and his Executive Assistant Steven M. Fetter, begins with the following preface:

Potential conflict between current Federal labor laws and labor-management cooperative efforts has led the U.S. Department of Labor to embark on a study, using its own resources and inviting the assistance of outside experts, to review the nation's labor laws and collective bargaining traditions and practices that may inhibit improved labor-management relations. The study is designed to assess whether the existing framework impedes, or, indeed, totally bars, many of the cooperative efforts the Department is encouraging and publicizing; and, if so, whether, through interpretation or modification, the laws can be made to support both the ingredients and the goals of labor-management cooperation rather than conflict with them. ${ }^{88}$

Undersecretary Schlossberg is a prior General Counsel of the United Auto Workers, a liberal Democrat, and certainly a friend of labor. ${ }^{89}$ The report traces the history and success of a number of cooperative labor-management efforts with special attention to the automobile industry, the General Motors Saturn Project, and other similar joint endeavors. It calls for a reexamination of the NLRA and federal labor policy, especially those portions of that policy which are dominated by conflict, an adversarial relationship, or designed-in impediments to voluntary labor-management cooperation. The report argues that

[i]n fifty years, we have progressed from a time when employers held absolute power, through a period when most employers allowed unions to set work rules and secure virtually automatic wage increases in return for yielding any right to have a say in the management of the company, to today, when some employers have come to understand that the worker on the shop floor might be able to provide insights which could help the enterprise succeed. . . . Clearly, cooperation and problem- solving offer

\section{Id.}

87. See generally Bureau of Labor-Management Relations and Cooperative Programs, U.S. Dept. of Labor, U.S. Labor LaW and the Future of Labor-Management Cooperation (1986) [hereinafter DOL REPORT].

88. Schlossberg \& Fetter, Preface to DOL REPORT, id.

89. Deputy Undersecretary Schlossberg is a past partner of the author and the source of whatever intellectual stimulation generated this article. His ORGANizing AND THE LAW is the recognized standard guide to successful union organizing under the NLRA. The DOL report is expressly designed to engender the debate which, it is hoped, is carried forward here. See generally $\mathrm{S}$. Schlossberg, Organizing and the Law (3d ed. 1984). 
more promise for productive labor-management relationships than the combat of the past. 90

Whether the United States ever actually experienced a period when "most employers allowed unions to set work rules and secure virtually automatic wage increases" is highly questionable. Outside the automobile industry, and perhaps a handful of similar sectors, no such situation ever existed. It may very well be true that once a labor force is highly organized, articulate, and capable of exercising united economic force vis-a-vis its employer, it is "allowed by management" to play a role in setting work rules. However, such cooperative endeavors are likely to arise in the future, as they have in the past, out of union recognition and successful bargaining under the NLRA model. Such success should be left to the parties and cannot be fairly imposed by the government when employer power is central and concentrated and faces disorganized individual employees.

Designing the contours of what labor and management decide to do in equalized power situations is an endeavor in which the government in a free enterprise society should play no role whatsoever. The DOL report argues as follows:

Government, too, has a legitimate role to play in the process. Government is obliged to provide a legal system which allows parties to work together to solve their mutual and individual problems and meet their mutual and individual needs. . . .

... The law must respond to two types of individuals - those who desire the flexibility to cooperate and those who require protection from the unscrupulous. Government must work to ensure that, if a [labor law] reform [on a cooperative model] is undertaken, all sides and all points of view are ably represented. . . ${ }^{91}$

All of this casts government in a completely different role than that anticipated under the NLRA model. In the NLRA model the role of government is not to concern itself with, or involve itself in, judging the results of a properly operating process. How could government judge who are those "individuals who desire flexibility to cooperate" and those who are "unscrupulous?" How is it to differentiate the bad guys from the good? Is it the role of government to make such judgments, especially in the economic sphere? If it is, should not the required determinations and planning mechanisms be far more conscious, open, and sophisticated than the mechanisms now in place? To the degree that the DOL's consideration of a cooperative model of labor relations merits attention, it merits such attention only by private actors making decisions based on established and mature relationships between employers ready to share traditional management prerogatives and employees who are fully organized, well-established and equal collective bargaining partners in workplace decision making. Such situations are comparatively rare in the United States, where only twenty percent of the workforce is represented, and far less than twenty percent of employers are ready to share such power. The few, which DOL extols, should not drive the basic labor policy.

90. DOL REPORT, supra note 87, at 31-32.

91. Id. at 30 . 
D. The Need for Reinvigorated Union Power: NLRA Straightjacketing, Industry Capture, and Politicization

The difference between the goals set in the NLRA in 1935 and current reality is not that the Act has been too successful, nor is it that labor has amassed too much power. Rather, the difference is that, after twenty-five years of advancing toward a goal of establishing collective bargaining and democratic unionism in the American workplace, the national policy commitment toward representation in collective bargaining of all American workers has suffered a twenty-year backslide. The same figures developed by Professor Weiler which showed real success in the first quarter century after the NLRA show losses thereafter. Since 1965, labor representation has been on the decline.

Why has this occurred? The most compelling answer lies in historical developments similar to those now generating the erosion of trusts in employee benefit investment management. Just as the bureaucratic dangers of straightjacketing, industry capture, and politicization are undermining common law trustees as independent financial decision makers, they are undermining the expansion of collective bargaining and unionism as the NLRA's answer to concentrated self-seeking corporate power.

During the NLRA's first twenty-five years, national labor policy sought and found constant growth toward collective bargaining as the central mechanism controlling the division of income between management and labor. The mechanism required minimum governmental intervention or planning. However, as NLRB organizional and representational rules and policies became better known, and more and more subject to test and abuse, their flexibility was reduced. The goal of increased union representation became frustrated by union certification election procedures which generated an increasing role for management as an active opponent to union certification. Gradually this resulted in industry capture that intensified with the Reagan Revolution and that politicized the system. Professor Weiler again shows this trend convincingly in a table outlining unfair labor practices by employers. 
TABLE IV

Unfair Labor Practices by Employers, 1950-198092

\begin{tabular}{|c|c|c|c|c|c|c|}
\hline Year & $\begin{array}{l}\text { Certification } \\
\text { Elections }\end{array}$ & $\begin{array}{c}\text { Charges } \\
\text { Against } \\
\text { Employers }\end{array}$ & $\begin{array}{c}\S 8(a) 3 \\
\text { Charges }\end{array}$ & $\begin{array}{l}\text { Fraction } \\
\text { Found } \\
\text { Meritorious }\end{array}$ & $\begin{array}{l}\text { Backpay Awards } \\
\text { (Average Amount) }\end{array}$ & Reinstates \\
\hline 1950 & 5619 & 4472 & 3213 & NA & $\begin{array}{c}2259 \\
(\$ 477)\end{array}$ & 2111 \\
\hline 1955 & 4215 & 4362 & 3089 & NA & $\begin{array}{l}1836 \\
(\$ 428)\end{array}$ & 1275 \\
\hline 1957 & 4729 & 3655 & 2789 & NA & $\begin{array}{l}1457 \\
(\$ 354)\end{array}$ & 922 \\
\hline 1960 & 6380 & 7723 & 6044 & $\begin{array}{c}29.1 \% \\
\text { (overall) }\end{array}$ & $\begin{array}{l}3110 \\
(\$ 335)\end{array}$ & 1885 \\
\hline 1965 & 7576 & 10,931 & 7367 & $\begin{array}{c}35.5 \% \\
\text { (overall) }\end{array}$ & $\begin{array}{c}4644 \\
(\$ 599)\end{array}$ & 5875 \\
\hline 1970 & 7773 & 13,601 & 9290 & $\begin{array}{c}34.2 \% \\
\text { (overall) }\end{array}$ & $\begin{array}{c}6828 \\
(\$ 403)\end{array}$ & 3779 \\
\hline 1975 & 8061 & 20,311 & 13,426 & $\begin{array}{c}32.3 \% \\
\text { (employer) } \\
30.2 \% \\
\text { (overall) }\end{array}$ & $\begin{array}{c}7405 \\
(\$ 1524)\end{array}$ & 3816 \\
\hline 1980 & 7296 & 31,281 & 18,315 & $\begin{array}{c}39.0 \% \\
\text { (employer) } \\
35.7 \% \\
\text { (overall) }\end{array}$ & $\begin{array}{c}15,642 \\
(\$ 2054)\end{array}$ & 10,033 \\
\hline
\end{tabular}

In 1939, the NLRB reinstated 7,738 employees who had been discriminatorily discharged due to their involvement with unions. ${ }^{93}$ As one would expect, once the principle of the rights of self-organization had been clearly enunciated and enforced by the government, the illegal use of the discharge declined. By 1957 the number of illegally dismissed employees offered reinstatement by the NLRB was a mere $922 .{ }^{94}$

After 1957, however, there was a suprising reversal of the trend. And by 1980 unfair labor practice charges against employers had risen $750 \%$. Furthermore, by the beginning of this decade, 10,033 employees were entitled to reinstatement. This number represents a $1000 \%$ increase from $1957 .{ }^{95}$

From his data, Weiler concludes that

... [a]stoundingly, then, the current odds are about one in twenty that a union supporter will be fired for exercising rights supposedly guaranteed by federal law a half-century ago. Such a widespread pattern of employer intimidation has ramifications that reach far beyond the units in which discharges actually occur. It fosters an environment in which employees will take very seriously even subtle warnings about the consequences of joining a union. ${ }^{96}$

Weiler's discussion and statistics demonstrate the trend toward industry capture of an administrative system established for the express purpose of

92. Weiler, supra note 82 , at 1780 .

93. Id. at 1779 .

94. Id.

95. For Weiler's analysis of the data represented by his chart, see id. at 1778-81.

96. Id. at $1780-81$. 
increasing the portion of the American workforce represented by unions. Clearly, industry capture is undermining that system.

Beyond this, an increased politicization of the process has further undermined the pro-unionization policy directive of the Act. The Reagan Administration entered office as a pronounced anti-labor administration, and statistics compiled by the AFL-CIO Lawyers Coordinating Committee indicate that Reagan has used his appointment power to politicize the NLRB. ${ }^{97}$

[O]ver the two-year period from September 1983, when President Reagan's appointees attained a majority on the National Labor Relations Board, through August 1985, when Member Hunter left the agency for an acknowledged employerside labor practice, ... . the percentage of unfair labor practice cases decided favorably to employers remained constant: From September 1984 through August 1985, as from September 1983 through July 1984, complaints against employers were sustained in approximately $50 \%$ of the contested . . . cases, while complaints against unions were sustained in about $85 \%$ of the contested . . . cases. ${ }^{98}$

These figures contrast sharply with those from the two previous periods, during which the Board was dominated first by Republicans, and then by Democrats. Although different in their political complexions, the Board chaired by Betty Murphy in the 1975 to 1976 period and the Board chaired by John Fanning in the 1979 to 1980 period, each ruled against employers and against unions with almost equal frequency. ${ }^{99}$

The same study shows that in representational cases, the percentage decided in management's favor was thirty-five percent in the 1975 to 1976 period, and forty-six percent in the 1979 to 1980 period. In the 1983 to 1984 period, the percentage of representation cases decided in accord with the employer's position jumped to seventy-two percent. ${ }^{100}$

97. AFL-CIO Lawyers Coordinating Comm., NLRB Decisional Patterns: Comparing the Dotson Board's Record, in The Labor Law Exchange, Dec. 1985, at 8.

98. Id. at 7.

99. Id.

100. Id. 
TABLE V

Contested Unfair Labor Practice Cases ${ }^{101}$

\begin{tabular}{|c|c|c|c|c|}
\hline \multicolumn{5}{|c|}{ CONTESTED UNFAIR LABOR PRACTICE CASES* } \\
\hline & $1975-76$ & 1979-80 & 1983-84 & 1984-85 \\
\hline $\begin{array}{l}\text { Complaint Against Employers Sustained in Whole } \\
\text { or Substantial Part }\end{array}$ & $470(84 \%)$ & $642(84 \%)$ & $189(51 \%)$ & $206(52 \%)$ \\
\hline $\begin{array}{l}\text { Complaint Against Employers Dismissed in Whole } \\
\text { or Substantial Part }\end{array}$ & $92(16 \%)$ & $126(16 \%)$ & $181(49 \%)$ & $188(48 \%)$ \\
\hline $\begin{array}{l}\text { Complaint Against Unions Sustained in Whole or } \\
\text { Substantial Part }\end{array}$ & $96(73 \%)$ & $84(74 \%)$ & $108(86 \%)$ & $110(86 \%)$ \\
\hline $\begin{array}{l}\text { Complaint Against Unions Dismissed in Whole or } \\
\text { Substantial Part }\end{array}$ & $36(27 \%)$ & $29(26 \%)$ & $18(14 \%)$ & $18(14 \%)$ \\
\hline \multicolumn{5}{|c|}{ REPRESENTATION CASES } \\
\hline Decisions in Accord With Employer's Position & $94(35 \%)$ & $73(46 \%)$ & $63(72 \%)$ & $65(66 \%)$ \\
\hline Decisions in Accord with Union's Position & $177(65 \%)$ & $86(54 \%)$ & $25(28 \%)$ & $34(34 \%)$ \\
\hline
\end{tabular}

* In compiling the statistics presented here, all contested decisions in unfair labor practice and representation cases issued by the NLRB during the time period studied were reviewed, eliminating backpay determinations, work awards under $\$ 10 \mathrm{k}$, applications for attorneys' fees, cases decided on procedural or jurisdictional grounds, and summary judgments granted in technical refusal to bargain cases and in uncontested $\$ 8(a)$ and $\S 8(b)$ cases. Excluded from the sample also were those contested $\S 8(a)$ and $\S 8(\mathrm{~b})$ cases in which the result could not fairly be characterized as favorable or unfavorable to the charged party; for the most part these were the cases in which the board sustained certain of the complaint allegations but dismissed others of roughly equal number and/or seriousness.

\section{E. Cooperation versus Competition: A Threat to Private Centers of} Workplace Power

Perhaps there is more than meets the eye in the current trend toward announcing the end of the labor movement and the rise of a new cooperative era in which labor and management will work together voluntarily without the need of organizational representation of employees. Cooperation is, of course, an attractive idea. Who could oppose it? However, those who offer cooperation in the workplace with a resulting need to replace the NLRA competitive model, should realize that the cooperative ideal as an engine of governmental labor policy endangers the NLRA's commitment to free market control of labor and its costs through balanced collective bargaining. Concentrated corporate power can not "cooperate" on any truly equal footing absent forceful collective labor power. Current conservative tax, antitrust, and financial decision making foster increasing corporate concentration. Increased support must be generated to foster aggressive collective employee power as a counterweight.

There is indeed a problem with current American labor law; the policy goal of collective bargaining as the employer-employee relations system of choice is in jeopardy. The abandonment of a pronounced and intentional pro-collective labor system weakens the American market system. A reinvigorated NLRA offers the best hope of decentralized power in the workplace without extensive intervention by the government. The NLRA represented a national policy commitment to the privatization of labor relations through governmentally fostered private, independent unionism. 
The Act should be turned to that purpose again. Professor Weiler, for example, offered suggestions as to how that might be done.102 What is needed in the American workplace is not governmentally fostered cooperation in the form of corporate volunteerism but rather a renaissance of the 1935 to 1965 vigorous unionization of the workplace.

\section{IV}

\section{Conclusion}

The Threat of Deprivatization and the Need for Noncorporate, Nongovernmental Centers of Power

For six years now, the national government has been controlled by conservatives who claim to be the century's strongest advocates of small government, privatization, and freely operating nongovernmental power centers. Surprisingly, over that period, corporate economic power has become increasingly concentrated while existing noncorporate centers of economic power have been systematically challenged by governmental straightjacketing, industry capture, and politicization.

Two of these challenges are evident in the recent trends toward the deprivatization of the management of employee benefit plan assets, and support for the replacement of a competitive based employee relations model, which fosters free union power as a market counterweight to concentrated corporate power, with a cooperative model, which fosters voluntary joint employee management cooperation.

102. See Weiler, supra note 82, at 1769-70. Weiler suggests that the goals and purposes of the Act can be achieved only by replacing the existing structure of the protracted representation campaign with "instant elections" modeled on the Canadian labor law regime. Id. 
